DOI https://doi.org/10.18551/rjoas.2021-02.12

\title{
WOMEN INVOLVEMENT IN CASSAVA VALUE CHAIN AMONG CASSAVA PROCESSORS AND MARKETERS IN AFIJIO LOCAL GOVERNMENT AREA, OYO STATE, NIGERIA
}

\author{
Azeez F.A. ${ }^{1 *}$, Usman J.M. ${ }^{1}$, Obadimu O.O. ${ }^{2}$, Mukarumbwa P. ${ }^{3}$, Kabir G.B. ${ }^{2}$ \\ ${ }^{1}$ Federal College of Forestry, Oyo State, Nigeria \\ ${ }^{2}$ Forestry Research Institute of Nigeria, Oyo State, Nigeria \\ ${ }^{3}$ University of Lesotho, Lesotho \\ *E-mail: fazeez2013@gmail.com \\ ORCID: 0000-0002-2153-7494
}

\begin{abstract}
There have been several governmental approaches and interventions to increase the production of cassava crop in Nigeria which have not been yielding desired results due to market linkage failure. This study seeks to assess women involvement in cassava value chain among cassava processors and marketers in Afijio Local Government of Oyo States. Two - stage sampling procedure was used to select the respondents for the study. Simple descriptive statistics such as mean, frequency counts and percentages were used to analyze the socio-economic characteristics of the respondents while Likert scale descriptive analysis was used to determine the level of participation of women involving in cassava value chain and ordinary least squares multiple regression analysis was adopted to determine the factors influencing the involvement of women in cassava value chain. The study concluded that women in the study area usually involve in promotion, publicity, fermenting the cassava flour, price reduction and packaging. Also, educational statuses, membership of cooperative association and farm credit access affect participation of women in cassava value chain among cassava processors and marketers in Oyo State. The study urged the Government to intervene in the business by making the processing and marketing of cassava friendly through an improved technology as well as provision of easily accessed credit facilities.
\end{abstract}

\section{KEY WORDS}

Production, involvement, cassava, women, processing, marketing.

Cassava is a staple food that is mostly produced by farmers In Nigeria. Although, the raw materials from cassava has restrained significance to agribusiness sector because cassava itself can be used as industrial raw materials, and it can also be transformed into various products like Gari, cassava flour (comprising Fufu and lafun), cassava chips, and cassava starch and taken them as industrial raw material. Its potential industrial uses mainly include alcohol industry, food industry and other non-food industry. Other industrial secondary products obtainable from cassava include pellets, adhesives and alcohol (ethanol) which are important raw materials in the livestock, alcohol/ethanol, confectionery, feed, wood, textile, food stuff and soft drinks industries [African Research Council (ARC), 2013].

However, cassava production frontier and its sub-sector required additional expansions to upturn its contribution to human well-being. Generally, agricultural sector value-chain structure remained one of the approaches that can enhance livelihood productivity (Adeoye et al., 2018). This value chain framework explains array of activities that are essential in bringing a product from its origin, via a certain design, obtaining raw materials and transitional inputs, marketing and distribution, to the end user (Kumar et al., 2011). This notion of value chain framework enshrined its proper utilization (USAID, 1992).

Indeed, the value chain approach promote desired inclination and emphases on connecting households to rising markets in order to allow such households to get income to procure extra food, goods and services. This may expand their food and minimize the threat of depending exclusively on their own production for their food security (USAID, 1992). According to ARC (2013), the chain of supply of cassava products starts with minimal 
production components, followed by minimal processing components with respect to the drying and/or milling of cassava.

In Nigeria, several governmental approaches and interventions like Presidential Initiatives on Cassava Crop were attempted to increase the production of cassava crop (Ahmed, 2009). But, while the measures achieved largely an average performance in the desired objective of increased production, it was a short lived situation before it became evident that there was a missing link in such developmental policy conception and application. The missing link is the market linkage analysis otherwise called value chain analysis (value addition) of cassava produce. The resultant effect of this missing link are depressed prices and market failures, which becomes disincentives to the farmers both individually and collectively (Ahmed, 2009).

However, there is a substantial link between cassava and women in sub-Saharan Africa to the extent that cassava is usually called a 'woman's crop' (World Bank, 2009). Women often play a very active role in the selling phase. According to Rahman (2004), 'the women are clever in price negotiation - women are better than men in price negotiation'. Also, the strength of Nigerian women in the cassava farmer groups is that they are good at price negotiation and processing planning (Rahman, 2004). Women contribute majorly to food and cassava production and processing, (Mgbada, 2002; Rahman, 2004).

Owing to the above insight, the study seeks to assess women involvement in cassava value chain among cassava processors and marketers in Oyo State with a specific reference to Afijio Local Government Area. Precisely, the paper (i) women participation level in cassava value chain (ii) identifies the key constraints to cassava value chain among the cassava processors and marketers and (iii) determines factors influencing women involvement in cassava value chain in the study area.

\section{METHODS OF RESEARCH}

This study was carried out in Afijio Local Government area of Oyo State Nigeria. It is located in the South-western zone of the state between latitude $7^{0} .8^{1}$ and $4^{0} .4^{1} \mathrm{~N}$ of the equator. It has an area of $1.365 \mathrm{~km}^{2}$ with roughly thirty townships and rural communities and a population of 102,250 using $3 \%$ projected growth rate as provided for by the Nigeria Population Commission (from 2012 census to 2019). There are 10 wards in Afijio Local Government Area which include: Aawe I, and II, Iware and Imini, Ilora I, II, and III, Fiditi I. and II, and Akinmorin/Jobele. Major towns in the LGA includes Akimorin, Ilu-aje, Imini, Jobele, Aawe-llora and Fiditi. In the west, Afijio LGA is surrounded by Akinyele LGA and by Oyo west Local Government Area in the east. The choice of Afijio Local Government Area as the study area was based to its prevalence of cassava processors and marketers within the state. This assertion was confirmed during the reconnaissance survey that was undertaken by the researcher prior to the field work. The study was targeted to women cassava processors and marketers in Afijio Local Government Area, Oyo State.

A two - stage sampling procedure was used in selecting the respondents for the study. Stage 1 involved the purposive selection of three wards in Ilora town (Ilora I, Ilora II and Ilora III). This selection was due to the presence / availability of cassava processors and marketers in these communities. The second stage was the random selection of the thirty women involved in cassava processing and marketing in each of the sampled communities to make a sample size of 90 respondents. Structured questionnaire and interview guide were used to collect relevant information from the respondents. Some of the information obtained centered on socioeconomic characteristics of women who process and market cassava products and general mode of operations relating to cassava processing and marketing activities in the study area.

Descriptive statistics (mean, frequency counts and percentages) were used to examine the demographic features of the respondents but Likert scale and participation index descriptive was used to investigate the participation level and the constraints to cassava value chain among cassava female processors and marketers respectively. The index was made by means of a 4 point Likert scale as participation were stated using 1-4 ordering scale 
(such as never participated, rarely participated, averagely participated and always participated. Different levels of participation were indicated by the respondents while their mean score across processing and marketing activities were computed and the ratio of the grand mean and the number of activities were determined. Further, Ordinary Least Squares multiple regression analysis was adopted to determine factors influencing women involvement in cassava value chain in the study area. Various methods of production function like linear, semi-log, exponential, and double log were studied while conventional economic statistical and econometric criteria were considered for the concluding selection of production function being adopted for the economic analysis.

The participation function espoused for women processors and marketers in the study area is implicitly presented by equation (3).

$$
Y=f\left(X_{1}, X_{2}, X_{3}, X_{4}, X_{5}, X_{6}, U i\right)
$$

Where: $Y=$ Participation index of the respondents; $X_{1}=$ Age of the respondents (years); $X_{2}=$ Year of experience (years); $X_{3}=$ Level of education (number of years spent in formal schooling); $X_{4}=$ Access to credit; $X_{5}=$ Extension contact (number of visit), $X_{6}=$ Cooperative membership (years), $\mathrm{Ui}=$ the error term or disturbance term (which is assumed to have zero mean and constant variance).

\section{RESULTS AND DISCUSSION}

Table 1 reflects the demographic features of the respondents in the study area. About $33 \%$ of the women cassava processors and marketers fell between age 31 and 40 years, twenty -eight percent were between $41-50$ years, while $21 \%$ were less than or equal to 30 years, $13 \%$ were between 51 and 60 years and very few (4\%) were above 61 years of age.

Table 1 - The Socio-economic Characteristics of Respondents

\begin{tabular}{lll}
\hline VARIABLES & FREQUENCY & PERCENTAGE (\%) \\
\hline Age & & \\
$20-30$ & 19 & 21.3 \\
$31-40$ & 29 & 32.6 \\
$41-50$ & 25 & 28.1 \\
$51-60$ & 12 & 13.5 \\
$>61$ & 4 & 4.5 \\
Marital Status & 20 & 22.5 \\
Single & 56 & 62.9 \\
Married & 4 & 4.5 \\
Divorced & 9 & 10.1 \\
Widow & & \\
Religion & 46 & 51.7 \\
Christianity & 41 & 46.1 \\
Islam & 2 & 2.2 \\
Traditional & & \\
Education & 34 & 38.2 \\
No formal & 15 & 16.9 \\
Adults & 8 & 9.0 \\
Primary & 20 & 22.5 \\
Secondary & 12 & 13.5 \\
Tertiary & & \\
Farming and Marketing Experience & 25.8 \\
1-5 & 23 & 22.5 \\
6-10 & 20 & 15.7 \\
11-15 & 14 & 36.0 \\
>16 & 32 & \\
Labour & & 19.1 \\
Family & 17 & 50.6 \\
Hire & 45 & 4.5 \\
Friends & 4 & 25.8 \\
All of the above & 23 & \\
\hline & &
\end{tabular}

Source: Field survey, 2019.

It indicates that large numbers of the respondents (about 54\%) were in their active ages and have sufficient energy to execute the task of cassava processing at any given time 
and space. It is however logical and consistent with the findings of Onuebunwa and Adesope (2012) and Onyemauwa et al., (2007) who posited that women in their early 30s and early 50 s usually participate in their large number in food crop processing.

Furthermore, marital status of the respondents revealed that about $63 \%$ of the respondents were married while $22.5 \%$ were single, $4.5 \%$ and $10.1 \%$ of them were divorced and widowed respectively. This result is in agreement with the finding of Olagunju et al., (2012) on related subject in South Western Nigeria who put forward that majority $(52.3 \%)$ of Gari marketers in the area were married which may have a positive effect on the availability of family labour.

In terms of religion being practiced by the respondents, many (52\%) of the respondents were Christians and $46 \%$ were Muslims. This indicates that religion does not really determine the participation of women in cassava processing and marketing in the study area. As regards the educational status of the respondents, most $(63 \%)$ of the respondents undertook one level of education or the other and $38 \%$ had no formal education. This is an implication that majority of the respondents were literates. This aligns the findings of Olagunju et al., (2012) who posited that majority of Gari processors and marketers in South-western Nigeria were literates.

Type of labour used indicates that $51 \%$ and $19 \%$ of the respondents made use of family and hired labour respectively while $5 \%$ made use of friends and $26 \%$ utilized all the types of labour available. This implies that respondents used the type of labour most convenient or available to them.

The result as shown in table 2 indicates that women averagely involved in most of the agricultural marketing and processing practices in the study area. For instance, participation in the activities such as peeling and washing, sieving, frying and good customer relation with mean of $3.98,3.95,3.89$ and 3.94 respectively were most significant indicating that women always participate in these activities.

Similarly, women in the study area usually involve in promotion, publicity, fermenting the cassava flour, price reduction and packaging (mean of 2.98, 2.94, 2.92, 2.92 and 2.89 respectively). On the other hand, women rarely participate in bagging and pressing/tying with stakes (mean=1.88 and 1.85). The grand mean for the participation index, which was found to be 23.04, is an indication that women in the study area always involve in cassava processing and marketing in the study area. This outcome supports the finding of Onyemauwa (2012) which indicated that women in Imo State of Nigeria always participate in cassava production and processing.

Table 2 - Level of Women Involvements in Cassava Processing and Marketing Value Chain

\begin{tabular}{|ll|}
\hline Cassava Processing/Marketing Value Chain & Mean score \\
\hline Peeling/Washing & 3.98 \\
Grating/Grinding & 2.36 \\
Bagging & 1.88 \\
Tying with stakes/ Pressing & 1.85 \\
Sieving & 3.95 \\
Frying & 3.89 \\
Fermenting & 2.92 \\
Packaging & 2.89 \\
Publicity & 2.94 \\
Promotion & 2.98 \\
Price reduction & 2.92 \\
Good relation with customer & 3.94 \\
Grand mean & $\mathbf{3 . 0 4}$ \\
\hline
\end{tabular}

Source: Field survey data, 2019.

Note: rarely involved =1.00-1.99; averagely involved $=2.00-2.99$; always involved $=3.00-3.99$. 
Results in table 3 revealed that high cost of processing (74\%) was found to be the highest constraint being encountered in their businesses along the value chain. This was followed by lack of machinery and infrastructural facilities (73.0\%), high cost of labour $(66.3 \%)$, market competition $(65.2 \%)$ and bureaucracy among the market groups' leadership respectively. In the same vein, among other constraints that were less severe include: house chores $(57.3 \%)$ noting the fact that the respondents were female. This is plausible since women would definitely engage in various forms of domestic activities which are capable of affecting their commitments, potentials and economic viability in their businesses.

Besides, the following less severe constraints were also identified by the respondents in the study area: $52 \%$ agreed with inadequate capital while $46 \%$ and $43 \%$ of the respondents opined that inadequate capital and price fluctuation were also encountered and $43 \%$ maintained high cost of publicity. This outcome does not mean that those less constraints were not negatively affecting the growth of their businesses but rather, they were not as bad as those severe constraints. Based on the field experience during the research findings, virtually all the itemized constraints constitute menace to cassava processing and marketing value chain in the study area. This finding corroborates the outcome of similar research carried out by Adeoye et al., (2018) in Ibarapa Central Local Government of Oyo State where virtually all of the above identified constraints were revealed in varying degrees.

Table 3 - Constraints Faced by Women Involving in Cassava Processing and Marketing

\begin{tabular}{|c|c|c|c|c|}
\hline Constraints & D & A & S A & Rank \\
\hline In adequate capital & $14(15.7)$ & $46(51.7)$ & $29(32.6)$ & 8th \\
\hline Lack of machinery & $16(18.0)$ & $65(73.0)$ & $8(9.0)$ & 2nd \\
\hline \multicolumn{5}{|l|}{ Pre occupation with } \\
\hline House chores (stress) & $25(28.1)$ & $51(57.3)$ & $13(14.6)$ & 7th \\
\hline High cost processing & $18(20.2)$ & $66(74.2)$ & $5(5.6)$ & 1 st \\
\hline \multicolumn{5}{|l|}{ Lack of infrastructural } \\
\hline Facility & $16(18.0)$ & $65(73.0)$ & $8(9.0)$ & 2nd \\
\hline High cost of labour & $17(19.1)$ & $59(66.3)$ & $13(14.6)$ & $3 \mathrm{rd}$ \\
\hline Lack of transportation & $14(15.7)$ & $56(62.9)$ & $19(21.3)$ & 6th \\
\hline High cost publicity & $19(21.3)$ & $38(42.7)$ & $32(36.0)$ & 10th \\
\hline \multicolumn{5}{|l|}{ Marketing } \\
\hline Bureaucracy & $24(27.0)$ & $56(62.9)$ & $9(10.1)$ & 5 th \\
\hline Market competition 2 & $26(29.2)$ & $58(65.2)$ & $5(5.6)$ & 4th \\
\hline Price fluctuation & $45(50.6)$ & $41(46.1)$ & $3(3.4)$ & $9^{\text {th }}$ \\
\hline
\end{tabular}

Source: Field survey, 2019.

The results of ordinary least squares multiple regression (Table 4) show that the linear functional form provided the lead equation of the factors that affect women involvement in cassava processing and marketing in the study area.

The linear form was chosen because it has the least standard error as well as one of the highest number of statistically significant $(p<0.05)$ exogenous variables, it also satisfied the a priori expectations. Table 4 reflects the determinants of women participation in cassava processing and marketing in the study site.

The semi-log forms and regression functions were not considered due to their very high standard error. Accordingly, the analysis is based on the result of the linear form. The results show that about $0.012 \%, 0.033 \%$ and $0.005 \%$ of the variation in the factors affecting women involvement in cassava processing and marketing in the area was explained by the exogenous variables included in the model. The study shows that there was a significant $(p<0.05)$ and positive relationship between women involvement in cassava processing and marketing in the study area and level of education, access to credit facilities, and cooperative 
participation. It can be adduced from the above results that as the women attain more education status, they are better prepared to involve in cassava processing and marketing.

Table 4 - Factors Influencing Women Involvement in Cassava Processing and Marketing

\begin{tabular}{|c|c|c|c|c|}
\hline Items & Linear function & Exponential function & Double -log & Semi-Log function \\
\hline Constant & 2.902 & & & \\
\hline \multirow{2}{*}{ Age } & 0.08 & 5.22 & -2.30 & 6.93 \\
\hline & $(0.51)$ & $(0.10)$ & $(0.19)$ & $(0.20)$ \\
\hline \multirow[t]{2}{*}{ Years of Experience } & 0.162 & -2.26 & -0.96 & 0.03 \\
\hline & $(0.19)$ & $(0.20)$ & $(0.35)$ & $(0.97)$ \\
\hline \multirow[t]{2}{*}{ Level of education } & 0.292 & -1.19 & 0.35 & -2.39 \\
\hline & $(0.01)^{*}$ & $(0.16)$ & $(0.71)$ & $(0.13)$ \\
\hline \multirow[t]{2}{*}{ Access to credit } & 0.083 & 2.09 & 0.63 & -1.02 \\
\hline & $(0.033)^{\star}$ & $(0.02)$ & $(0.53)$ & $(0.48)$ \\
\hline \multirow[t]{2}{*}{ Extension contact } & 0.094 & 0.94 & 0.86 & 1.27 \\
\hline & $(0.42)$ & $(0.27)$ & $(0.33)$ & $(0.14)$ \\
\hline \multirow[t]{2}{*}{ Cooperative participation } & 0.091 & -5.87 & -1.17 & 1.35 \\
\hline & $(0.00)^{*}$ & $(0.02)$ & $(0.19)$ & $(0.39)$ \\
\hline $\mathrm{R}^{2}$ & 0.27 & & & \\
\hline F value & 2.02 & & & \\
\hline $\mathrm{N}$ & 89 & & & \\
\hline Std E & 0.82 & & & \\
\hline
\end{tabular}

Source: Field survey, 2019.

*Significant at $10 \%$ level of significant.

Similarly, increased in credit facilities would increase the tendency of women to be involved in the processing activities because fund availability would allow them to process and market at full capacity. Likewise, the benefits inherent in cooperative membership enable the processors to have their inputs at reduced price due to bulk purchase and subsidy given by various institutional bodies from time to time. Expectedly, cooperative membership increased the propensity of the processors and marketers to be involved in cassava processing and marketing activities in the area. Earlier studies revealed that level of education, number of extension visits, farm income, cooperative participation (Onyemauwa, 2012), agricultural extension agents, and monthly income were significant factors that influence the involvement of women in cassava processing and marketing (Adeoye et al., 2018).

\section{CONCLUSION}

The study concluded that majority of women under investigation were in their active age, married, half educated and adopted mostly hired labour to augment their family labour input. Sieving, frying and good customer relation were the common practices while bagging and pressing/tying with stakes were the least practices among women cassava processors and marketers in the study area. Furthermore, high cost of processing was found to be the highest constraint while house chores pre-occupation was the least severe constraint that was upsetting the growth of their businesses along their value chains. Also, women in the study area usually involve in promotion, publicity, fermenting the cassava flour, price reduction and packaging. Lastly, educational statuses, participation in cooperative activities, as well as access to farm credit were significant factors that influence women involvement in cassava value chain among cassava processors and marketers in the study area.

\section{RECOMMENDATIONS}

From the findings of this research, the following recommendations were made:

- Government and the authority concerned should encourage cassava processors and marketers to expand their participation as their socioeconomic characteristics are favorable disposed to their chosen jobs. 
- Government should embark on empowerment programs for them through provision of modern equipment/machines and adequate infrastructural facilities in order to reduce the processing time and cost.

- Participation of women processors in cooperatives societies should be encouraged so as to leverage on the societies' assistance for their improvement.

- It also becomes imperative for the Government to intervene in the business by making the processing and marketing of cassava friendly through an improved technology as well as provision of easily accessed credit facilities

\section{ACKNOWLEDGEMENTS}

The Authors acknowledge the contribution of Forestry Research Institute of Nigeria and Federal College of Forestry for providing an enabling environment to undertake this work.

\section{REFERENCES}

1. African Research Council (ARC), 2013. Field crops: Cassava. Accessible at http://www.arc.agric.za/home.asp. Visited on 7th October 2013.

2. Ahmed, T., 2009. The Death of Cassava Dream: Nasarawa Lost Millions of Naira Due to Government Induced Cassava Glut. Sunday Trust Newspaper of June 9, 2009.

3. Ayoade, J. A., Ibrahim H. I., Ibrahim H. Y., 2009. Analysis of Women Involvement in Livestock Production in Lafia. "Consumption and Nutrition Survey 2001- 2003". Summary Report of International Institute of Tropical.

4. Kumar A., Singh H., Kumar S., Mittal S., 2011. Value Chains of Agricultural Commodities and their Role in Food Security and Poverty Alleviation - A Synthesis. Agricultural Economics Research Review, 24: 169-181.

5. Adeoye, A., Oyeleye, A.A., Ajibade, A.J., Daud, S.A, Alabi, A.F., and Amao S.A., 2018. Women Participation in Cassava Processing in Ibarapa Central Local Government Area of Oyo State, Nigeria. International Journal for Research in Agricultural and Food Science, Vol. 4 No. 4 Pp 15-28.

6. Mgbada, J. U., 2002. Production of Staple Crops by Rural Women in Enugu and Ebonyi States: Lessons for Enhancing Poverty Alleviation Programmes. In: Olowu T. A. (Ed.): Agricultural Extension and Poverty Alleviation in Nigeria. Proceeding of the Agricultural Extension Society of Nigeria, pp: 10-12.

7. National Bureau of Statistics, 2012. The Nigeria Poverty Profile 2010 Report of the National Bureau of Statistics Harmonized Nigeria Living Standard Survey (HNLSS).

8. Olagunju, F., Babatunde, R. and Salimonu, K., 2012. Market Structure, Conduct and Performance of Gari Processing Industry in South Western Nigeria. Research Paper. World Journal of Microbiology and Biotechnology, 10: 268-270.

9. Onuebunwa, B. N., Adesope, O. M., 2006. Contributions of women and children to backyard farm labour in Ikeduru area of Imo State, Nigeria. International Journal of Natural and Applied Sciences 2 (3): 189-192.

10. Onyemauwa, C.S., 2012. Analysis of Women Participation in Cassava Production and Processing in Imo State, Southeast Nigeria. Agricultura Tropica Et Subtropica, 45(2).

11. Onyemauwa, C.S. et al, 2007. Allocative Efficiency and Output Elasticity of Crop Mixture Farmers by Gender in Nwangele, Imo State, Nigeria. International Journal of Agriculture and Rural Development 10(2): 50-55.

12. Rahman, S. A., 2004. Gender Differential in Labour Contribution and Productivity in Farm Production Empirical Evidence from Kaduna State of Nigeria. Paper Presented at the National Conference on Family held at New Theatre Complex. Benue State University, Makurdi, Nigeria. 1st-5th March.

13. Sanni, M.O., 1991. Gari Processing in Ibadan Metropolis: Factors Controlling Quality at the Society for Tropical Root Crops (African Branch). Kinshasa, Zaire, 5-8: 229- 234.

14. USAID, 1992. Policy Determination: Definition of Food Security 3-4.

15. World Bank, 2009. Evolution of Poverty and Welfare in Nigeria. World Bank Policy. 